\title{
Kala dan Aspek pada Kata Kerja Iku dan Kuru dalam Bahasa Jepang
}

\author{
Tense and Aspect of the Verbs Iku and Kuru in Japanese \\ Rahma Fitri Alifah \\ Universitas Padjadjaran \\ rahma19003@mail.unpad.ac.id
}

\begin{abstract}
In Japanese, there are verbs of $i k u$ which have a literal meaning 'away,' and verbs of kuru which have a literal meaning 'come.' However, in Japanese, the two verbs can have another meaning if viewed from the tense and aspects of a sentence. For Japanese learners, to distinguish between the use of Japanese language and aspects and knowing the meaning of sentences which are characterized by aspects is a complex matter. This study aims to analyze the types of aspects and tense of the $i k u$ and kuru verbs. This study uses written tapping techniques with data sources came from Japanese news media, The Daily Jakarta Shinbun, which was published on February 19, 2020. The conclusion of this research is that the type of aspects found in the verbs of -te $i k u$ and -te kuru are imperfective aspects and perfective. Furthermore, the type of tense contained in the verbs -te iku and -te kuru is to state the present, future, and past conditions.
\end{abstract}

Keywords: aspect, iku, kuru, tense

\section{INTISARI}

Dalam bahasa Jepang terdapat kata kerja $i k u$ yang memiliki makna harfiah pergi, dan kata kerja kuru yang memiliki makna harfiah datang. Tetapi, dalam bahasa Jepang, kedua kata kerja tersebut dapat memiliki makna lain jika ditinjau dari kala dan aspek dalam sebuah kalimat. Bagi pembelajar bahasa Jepang membedakan penggunaan kala dan aspek bahasa Jepang serta mengetahui makna kalimat yang dicirikan dengan aspek merupakan hal yang kompleks. Penelitian ini bertujuan menganalisis jenis aspek dan kala pada kata kerja $i k u$ dan kuru. Penelitian ini menggunakan teknik sadap secara tertulis dengan sumber data dari media cetak berita Jepang yaitu The Daily Jakarta Shinbun yang terbit pada tanggal 19 Febuari 2020. Simpulan dari penelitian ini adalah jenis aspek yang terdapat pada kata kerja -te iku dan -te kuru adalah terdapat aspek imperfektif dan perfektif, jenis kala yang terdapat pada kata kerja -te $i k u$ dan -te kuru adalah menyatakan kondisi saat ini, masa depan, dan masa lampau.

Kata Kunci: aspek, iku, kala, kuru

Panduan sitasi:

Alifah, R.F. (2020). Kala dan Aspek pada Kata Kerja Iku dan Kuru dalam Bahasa Jepang. JLA (Jurnal Lingua Applicata), 3(2), 132-141 


\section{PENDAHULUAN}

Bahasa adalah media komunikasi yang digunakan dalam sistem kemasyarakatan untuk menyampaikan hal-hal yang ada di benak para pengguna bahasa tersebut. Halhal yang berkaitan dengan auditori (bunyi), bentuk konkret bahasa tersebut (tulisan), dan sistem penggunaan bahasa (struktur) adalah termasuk ke dalam aspek bentuk. Linguistik adalah suatu bentuk ilmu yang mengkaji bahasa. Masing-masing bahasa memiliki kekhasan tersendiri yang membuat bahasa tersebut berbeda dengan bahasa yang lain. Di zaman dimana bidang industri apapun sudah maju saat ini, orang-orang sudah semakin peduli untuk memiliki kemampuan menguasai bahasa asing. Bahasa asing dikatakan sebagai bahasa kedua karena merupakan bahasa yang tidak kita kuasai di lingkungan keseharian. Dalam mempelajari bahasa kedua, sering terjadi kontak bahasa. Kontak bahasa terjadi saat pembelajar melakukan alih bahasa dari bahasa pertama (bahasa yang diajarkan di lingkungan keseharian atau dengan kata lain bahasa ibu) ke dalam bahasa kedua yang sedang dipelajari. Kondisi tersebut membuat pembelajar bahasa asing tidak sengaja melakukan kesalahan dengan menggunakan kebiasaan yang ada dalam bahasa pertama ke dalam penggunaan bahasa kedua.

Istilah yang menunjukan kondisi seperti ini disebut dengan interferensi, dengan kata lain interferensi adalah kesalahan tercampurnya kebiasaan yang ada pada bahasa pertama yang digunakan ke dalam bahasa kedua (Kridalaksana, 2009, p. 95).
Interferensi yang sering terjadi dari bahasa Indonesia yang merupakan sebagai bahasa pertama ke dalam bahasa Jepang yang merupakan sebagai bahasa kedua adalah pada pembentukan kala dan aspek. Kala menurut (Chaer, 2012, p. 260) adalah keterangan waktu yang menunjukan kapan perbuatan, kejadian, tindakan terjadi di dalam kalimat. Sedangkan aspek (Chaer, 2012, p. 259) adalah hal yang dilihat dari pembentukan waktunya untuk menggambarkan situasi, keadaan, kejadian, atau proses yang ada dalam kalimat tersebut. Aspek-aspek ini dalam bahasa Jepang memiliki penanda khusus. Dalam bahasa Jepang, terdapat kata kerja $i k u$ yang memiliki makna harfiah pergi, dan kata kerja kuru yang memiliki makna harfiah datang. Tetapi, dalam bahasa Jepang, kedua kata kerja tersebut dapat memiliki makna lain jika melihat dari segi kala dan aspek dalam sebuah kalimat.

Bagi pembelajar bahasa Jepang sering mengalami hambatan dalam penggunaan kala dan aspek. Oleh karena itu, peneliti tertarik untuk meneliti tentang penggunaan kala dan aspek pada kata kerja $i k u$ dan kuru dalam bahasa Jepang. Penelitian ini mengambil sumber data pada media cetak yang terbit pada bulan Februari 2020 karena artikel yang diberitakan pada media tersebut merupakan hal yang sedang terjadi saat ini, dan juga banyak mengandung kata kerja iku dan kuru yang mengandung aspek. Penelitian ini bertujuan untuk menganalisis jenis aspek dan kala pada kata kerja $i k u$ dan kuru. 
Kala (Iori, Takanashi, Nakanishi, \& Yamada, 2000, p. 40) adalah tense dalam suatu kalimat bahasa Jepang yang memiliki bentuk - $t a$ atau bentuk -ru. Tensu atau jisei memiliki definisi: 1) keadaan yang sedang terjadi pada saat tuturan diucapkan; 2) keadaan yang akan terjadi; 3) keadaan yang telah terjadi. Pada kalimat bahasa Jepang, yang mengalami perubahan untuk menunjukan kala terdapat pada predikat dalam sebuah kalimat, dimana predikat tersebut menunjukan keadaan yang telah disebutkan pada tiga kategori di atas. Penjelasan ketiga kategori di atas oleh Teramura (1998) adalah sebagai berikut:

(1) Watashi wa kyou uchi ni iru.

'Saya hari ini ada di rumah.'

(2) Watashi wa ashita uchi ni iru.

'Saya besok ada di rumah.'

(3) Watashi wa kinou uchi ni ita.

'Saya kemarin ada di rumah.'

Kalimat (1) dan (2) memiliki predikat kata kerja iru, meskipun memiliki keterangan waktu yang berbeda yaitu kyou 'hari ini' dan ashita 'besok'. Sedangkan pada kalimat (3) terdapat bentuk predikat ita. Perubahan bentuk pada kata kerja -ru, dalam kalimat ini iru menjadi bentuk kata kerja - ta pada ita merupakan hal yang menunjukan kala. Kalimat (1) dan (2) merupakan kala yang tidak menunjukan lampau, sedangkan kalimat (3) merupakan kala yang menunjukan lampau. Kala dalam bahasa Jepang tidak hanya ditunjukan dengan perubahan morfologis pada predikat, namun juga ditunjukan dengan kategori lain dalam hal ini keterangan waktu seperti ototoi 'dua hari lalu', kinou 'kemarin', kyou 'hari ini', ashita 'besok', senshuu 'minggu lalu', sengetsu 'bulan lalu', kyonen 'tahun lalu', dan lainnya. Penggunaan kala dalam bahasa Jepang menurut Yasuhiko \& Fukuchi (1989, p. 5) memiliki empat penggunaan dasar, yaitu bentuk $t a$ untuk aktivitas lampau, bentuk ta untuk kejadian lampau, bentuk ru untuk keadaan saat ini, dan bentuk ru untuk kejadian yang akan datang. Selain empat penggunaan ini, terdapat penggunaan kala lain yang dipaparkan dalam tabel 1. Empat penggunaan dasar kala diberi cetak tebal.

Tabel 1. Penggunaan kala

\begin{tabular}{|c|c|c|c|}
\hline $\begin{array}{c}\text { Jenis } \\
\text { Predikat }\end{array}$ & $\begin{array}{l}\text { Penggunaan } \\
\text { Bentuk -ta }\end{array}$ & \multicolumn{2}{|c|}{ Penggunaan Bentuk -ru } \\
\hline Kondisi & a. Kondisi Lampau & $\begin{array}{l}\text { d. Kondisi saat ini } \\
\text { e. Keyakinan kondisi masa depan }\end{array}$ & i. Kebenaran/kenyataan \\
\hline $\begin{array}{l}\text { Aktivitas } \\
\text { /Keja- } \\
\text { dian }\end{array}$ & $\begin{array}{l}\text { b. Kejadian Lampau } \\
\text { c. Kebiasaan/pengula- } \\
\text { ngan masa lampau }\end{array}$ & $\begin{array}{l}\text { f. Keyakinan kejadian masa de- } \\
\text { pan } \\
\text { g. Fenomena saat ini } \\
\text { h. Penjelasan prosedur/pengguna- } \\
\text { an }\end{array}$ & $\begin{array}{l}\text { j. Kebiasaan/pengulangan sa- } \\
\text { at ini }\end{array}$ \\
\hline
\end{tabular}

(Sumber: Yasuhiko \& Fukuchi, 1989) 
Menurut Kamus Besar Bahasa Indonesia (Alwi, dkk., 2005), kala adalah perbedaan bentuk kata kerja untuk menyatakan perbedaan waktu. Kala terdiri dari lampau, kini, dan mendatang untuk menunjukan perbedaan waktu dimana aktivitas atau keadaan tersebut terjadi (Kridalaksana, 2009, p. 103). Berbeda dengan bahasa Jepang, kala dalam bahasa Indonesia tidak ditunjukkan dengan predikat yang berubah bentuk, melainkan ditunjukkan dalam konteks kalimat. Misalnya:

(4) A: Kamu kemarin melakukan apa?

B: Aku menulis surat.

Pada tuturan yang diucapkan B dalam (4), tuturan tersebut tidak menunjukan adanya kala. Akan tetapi, jika melihat konteks tuturan seperti yang diucapkan oleh A yang menuturkan 'kemarin', hal itu menunjukkan bahwa aktivitas tersebut sudah dilakukan (lampau). Predikat dalam bahasa Indonesia tidak mengalami perubahan. Oleh karena itu, selain melihat konteks kalimat atau tuturan, ada penambahan keterangan waktu seperti 'kemarin', 'akan', 'besok', dan semacamnya. Kala juga ditandai dengan pemberian kata yang menunjukkan keterangan waktu seperti 'kemarin', 'akan', 'besok', dan lain-lain, tetapi pada predikat tidak mengalami perubahan.

Penjelasan mengenai aspek bahasa Jepang (Aryanto, 2008) dapat dilihat secara leksikal melalui: 1) predikat yang diisi kata kerja yang memiliki akhiran morfologis -ru dan -ta; 2) kata kerja yang terdapat imbuhan -te iru, -te aru, -rareteiru, -te shimau, -te kuru, - te iku; 3) predikat yang diisi dengan kata kerja majemuk; 4) kata kerja yang dilekati -tokoro (kata kerja -ru tokoro, kata kerja -ta tokoro, kata kerja -te iru tokoro) dan kata kerja -ta bakari.

Kala aspek (tensu aspekuto) dalam bahasa Jepang merupakan hal yang sulit dibedakan, terutama pada predikat yang diisi oleh kata kerja bentuk - ru dan -ta terdapat aspek imperfektif dan perfektif. Aspek imperfektif jika dilihat dari katanya, merupakan kata serapan dari bahasa Inggris perfect 'perfek' yang diberikan imbuhan im (menyatakan negasi), dengan asal kata imperfect 'tidak perfek/tidak sempurna/tidak selesai.' Dalam hal ini, imperfektif memiliki makna 'suatu aktivitas tidak selesai atau belum selesai.' Sedangkan perfektif bermakna 'aktivitas yang telah selesai.' Pada bahasa Jepang, aspek imperfektif ditunjukkan dengan kata kerja bentuk - $r u$, sedangkan aspek perfektif ditunjukkan dengan kata kerja bentuk -ta. Predikat yang diisi dengan kata kerja bentuk -te juga dilekati kata kerja -iru.

(5) Otto wa "aimu fain" to itta kagiri damatteiru

'(saya) terdiam semenjak suami(ku) berkata "I am fine".'

(6) Watashi wa isshoukenmei ni teepu de eigo wo kiite iru 'saya bersungguh-sungguh mendengarkan bahasa Inggris melalui kaset.' 
Kalimat (5) dituturkan dengan kata kerja bentuk -ru, yaitu damaru menjadi damatte iru, menyatakan keadaan saat kalimat tersebut dituturkan. Adapun kalimat (6) dengan kata kerja bentuk -ru, yaitu kiku menjadi kite iru, menyatakan aktivitas yang sedang terjadi. Kalimat (5) dan (6) memiliki bentuk kata kerja yang sama -te iru, tetapi berbeda makna. Perbedaan ini terjadi karena jenis kata kerja yang digunakan berbeda. Kalimat (5) menggunakan kata kerja intransitif, yaitu kata kerja tanpa objek langsung, sedangkan kalimat (6) menggunakan kata kerja transitif, yaitu kata kerja yang memerlukan objek. Simpulan dari kedua kalimat tersebut adalah aspek yang ada dalam tuturan tersebut merupakan aspek imperfektif.

Pada predikat yang diisi dengan kata kerja majemuk terdapat aspek perfektif dan imperfektif. Sebagai contoh, pada kata kerja majemuk yang dilekati kata kerja seperti hajimaru 'mulai', kata kerja ini termasuk ke dalam kategori aspek imperfektif karena hajimaru menunjukkan keadaan yang akan terjadi. Sedangkan kata kerja majemuk yang dilekati kata kerja pada contoh lain seperti owaru (selesai), kata kerja ini termasuk ke dalam aspek perfektif karena menunjukkan keadaan yang sudah terjadi.

Terdapat pula tipe predikat kata kerja yang diikuti -tokoro (kata kerja -ru tokoro, kata kerja -ta tokoro, kata kerja -te iru tokoro) dan kata kerja -ta bakari). Kala pada bentuk kata kerja mempengaruhi jenis aspek tipe ini. Kata kerja bentuk -ru + tokoro termasuk jenis aspek imperfektif, kata kerja bentuk -ta + tokoro termasuk jenis aspek perfektif, kata kerja bentuk -te $i r u+$ tokoro termasuk jenis aspek imperfektif, dan kata kerja bentuk - $t a+$ bakari termasuk jenis aspek perfektif.

\section{METODE PENELITIAN}

Dalam penelitian ini, penulis menggunakan metode kualitatif. Menurut Bogdan dan Taylor dalam Ratna (2016, p. 94), kualitatif adalah metode yang menghasilkan data dalam bentuk tertulis maupun tidak tertulis (lisan). Metode dan teknik adalah alat untuk mendapatkan hasil akhir dari sebuah penelitian. Kridalaksana (2009, p. 153) mengemukakan bahwa metode adalah cara untuk menjelaskan suatu keadaan dengan cara mendekati, mengamati, dan menganalisis keadaan tersebut. Pada penelitian ini, penulis menggunakan teknik sadap secara tertulis, yaitu dengan penggunaan bahasa tulis. Penulis memilah kalimat yang mengandung kata kerja iku dan kuru, dari beberapa kalimat yang di dapat, kemudian penulis mengklasifikasikan kata kerja iku dan kuru yang masuk ke dalam kategori aspek. Sumber data penelitian ini adalah data yang diperoleh dari media cetak berita Jepang yaitu The Daily Jakarta Shinbun yang terbit pada tanggal 19 Febuari 2020.

\section{HASIL DAN PEMBAHASAN}

Secara gramatikal, bahasa Jepang adalah bahasa yang memikirkan posisi sudut pandang pembicara, berdasarkan waktu ataupun arah perpindahan tempat 
dari suatu aktivitas. Tetapi, kata kerja -te $i k u$ dan -te kuru berperan penting dalam hubungan posisi sudut pandang pembicara. Pada dasarnya kata kerja -te iku dan -te kuru memiliki arti yang berlawanan, yaitu kata kerja -te iku digunakan untuk menunjukkan aktivitas perpindahan atau keadaan yang menjauh dari posisi pembicara. Adapun kata kerja -te kuru digunakan untuk menunjukkan aktivitas perpindahan atau keadaan yang mulanya menjauh dari posisi pembicara kemudian mendekat.

\section{Kata kerja - te kuru}

(7) 黄色で統一された店内に近づいてい くと、甘い香りが漂ってくる。

Kiiro de touitsu sareta ten'nai ni chikadzuite iku to, amai kaori ga tadayotte kuru.

'Saat pergi mendekati toko yang disatukan dalam warna kuning, aroma manis semakin tercium.'

Dalam kalimat (7) terdapat kata kerja chikadzuite iku dan tadayottekuru. Chikadzuite iku termasuk ke dalam aspek, karena -te $i k u$ dalam kalimat tersebut memiliki arti adanya proses perpindahan, subjek mendekati objek. Kemudian, tadayottekuru termasuk ke dalam aspek imperfektif, karena ada makna adanya perubahan, dari yang tadinya tidak tercium, semakin tercium. Dalam kalimat (7), objek bergerak mendekati pembicara, yaitu objek amai kaori 'aroma manis' bergerak mendekati posisi pembicara, sehingga pembicara semakin mencium aroma tersebut. Pada kalimat tersebut, kala menyatakan kondisi saat ini, kenyataan yang terjadi saat ini yang ditandai dengan akhiran bentuk -ru, yaitu te kuru.

(8) メンバーの木下碧花さんは「お客様 を楽しませたいという気持ちで練習 してきました。入賞できてうれしい です。と述べた。

Menbaa no kinoshita aoihana san wa [okyakusama o tanoshimaseta to iu kimochi de renshuu shite kimashita. Nyuushou dekite ureshii desu.] to nobeta.

'Seorang anggota, Aki Kinoshita mengatakan, "Saya telah berlatih dengan perasaan senang untuk menghibur penonton. Saya senang karena menang.'

Kalimat (8) merupakan kalimat majemuk yang termasuk klausa kutipan atau inyou setsu yang ditandai dengan to nobeta. Kata kerja sebagai inti proposisi pada kalimat ini ialah nobeta. Kata kerja nobeta berasal dari noberu kemudian mengalami perubahan bentuk dengan akhiran ta menjadi nobeta yang menyatakan kala lampau. Pada kalimat ini, kala menyatakan kejadian masa lampau berdasarkan titik waktu yaitu tanggal 19 Februari dan kejadian 'telah mengekspresikan' ini telah dilakukan sebelumnya dari waktu berbicara. Kemudian, renshuu shitekimashita, juga menyatakan kala kejadian masa lampau yang ditandai 
dengan kata kerja renshuu shitekuru menjadi renshuu shitekimashita. Kata kerja -te kuru dalam kalimat tersebut termasuk aspek perfektif. Hal ini disebabkan karena saat tuturan diucapkan aktivitas tersebut mendekati waktu saat dituturkan.

(9) 防犯ボランティアからも「返事をし てくれず寂しい」との声が聞こえて きますが、大切なのは見守る側があ いさつをやめなさいことです。

Bōhan borantia karamo 'henji o shite kurezu sabishī' to no koe ga kikoete kimasuga, taisetsuna no wa mimamoru gawa ga aisatsu o yame nasai kotodesu.

'Terdengar jawaban dari sukarelawan kriminal, "Saya kesepian karena tidak ada jawaban". Tetapi, yang paling penting adalah pihak pengawas hentikan salam.'

Pada kalimat (9) terdapat kata kerja kikoete kimasu yang memiliki arti 'saya mendengar suara yang datang'. Kata kerja kikoete kimasu di atas termasuk ke dalam aspek yang melekat pada kata kerja bantu. Kalimat (9) termasuk ke dalam jenis aspek imperfektif yang memperlihatkan adanya perubahan, yaitu dari kondisi yang sebelumnya tidak terdengar suara menjadi ada suara. Kata kerja kikoete kimasu termasuk ke dalam kala kondisi saat ini karena kata kerja -te kimasu berasal dari -te kuru.

(10)のどかな散策路の気持ちよさも相ま って、徐々に秘境感が増してきます。
Nodokana sansakuji no kimochi yosa mo aimatte, jojoni hikyoukan ga mashite kimasu.

'Dikombinasikan dengan perasaan dan jalan yang tenang, sedikit demi sedikit jalan yang belum dijelajahi sebelumnya semakin banyak tahu.'

Kalimat (10) memiliki kata kerja mashite kimasu yang termasuk ke dalam aspek imperfektif yang menyatakan 'dari sekarang ke depan'. Maksud yang ingin disampaikan adalah 'dari sekarang akan semakin banyak mengetahui jalan yang sebelumnya tidak diketahui oleh penutur. Penutur akan menjelajahi perjalanan tersebut dengan hati yang tenang sehingga akan menemukan jalan-jalan lain yang belum diketahui.' Kata kerja mashite kimasu memiliki makna bahwa pengetahuan tentang jalan akan semakin penutur dapatkan, pengetahuan tersebut akan semakin datang menghampiri penutur. Kata kerja mashite kimasu yang berasal dari kata kerja -te kuru termasuk ke dalam kala keyakinan kejadian masa depan, karena akan terjadi setelah titik waktu saat dituturkan.

\section{Kata kerja - te iku}

（11）生きる目的を漠然としか考えていな かった若者が、自分の余命がわずか だと知り、残された人生を模索して いく。

Ikiru mokuteki o bakuzen to shika kangaeteinakatta wakamono ga, jibun 
no yomei ga wazukada to shiri, nokosareta jinsei o mosaku shiteiku.

'Anak muda yang tidak memikirkan kejelasan tujuan hidup semakin mencari kehidupan yang tersisa dan menemukan bahwa ia memiliki sedikit harapan hidup.'

Pada kalimat (11) terdapat kata kerja mosaku shiteiku yang memiliki arti 'semakin meraba-raba' atau 'semakin mencari'. Mosaku shite adalah predikat yang menunjukkan aspek imperfektif yang melekat pada kata kerja bantu -te iku. Makna -te iku dalam kalimat ini adalah fenomena saat ini yang semakin jauh dari persepsi penutur. Kala dalam kalimat (11) adalah kondisi saat ini, karena mosaku shiteiku di akhiri dengan kata kerja -te iku yang termasuk kata kerja bentuk -ru. Dilihat dari konteks kalimat, tuturan ini diucapkan dengan melihat kondisi yang terjadi saat ini.

(12）出会いを通してその町ならではの歴 史や文化、風土、伝統、グルメなど を紹介していく。

Deai o tsuushite sono machi nara dewa no rekishi ya bunka, fuudo, dentou, gurume nado o shoukai shiteiku. 'Melalui pertemuan akan memperkenalkan sejarah, budaya, iklim, tradisi, dan hidangan khas kota itu.'

Kalimat (12) memiliki kata kerja shoukai shiteiku dengan arti 'semakin memperkenalkan'. Makna -te iku dalam shoukai shiteiku adalah menyatakan aspek imperfektif, yaitu keadaan yang akan terjadi dari sekarang ke masa depan. Kata kerja -te iku disini memiliki kesan bahwa keadaan setelahnya akan berbeda dengan keadaan di masa depan yang berarti keadaan tersebut akan semakin menjauhi penutur. Kala dalam kalimat ini adalah keyakinan kejadian masa depan, dilihat dari kata kerja shoukai shiteiku yang merupakan bentuk -ru.

（13）様々な人と触れ合いながらその町の 魅力を発見していくふれあいドキュ メントバラエティ。

Samazama na hito to fureai nagara sono machi no miryoku o hakken shite iku fureai dokyumento baraeti.

'Program televisi yang menampilkan temuan-temuan daya tarik kota itu sambil berinteraksi dengan berbagai macam orang.'

Kalimat (13) mengandung kata kerja hakken shiteiku yang memiliki arti 'semakin menemukan'. Makna -te iku dalam hakken shiteiku adalah menyatakan aspek imperfektif, yaitu keadaan dari saat ini ke depan. Dalam hal ini posisi penutur tetap, sedangkan temuan-temuan tersebut akan menjauhi penutur. Kala dalam kalimat ini adalah kondisi saat ini, karena berada dalam program televisi yang sedang tayang pada bulan Febuari 2020.

(14) みなさんも、地球温暖化対策の現状 をよく知って、大人の取り組みが十 


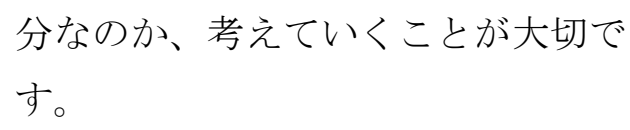

Minasan mo, chikyūondankataisaku no genjō o yoku shitte, otona no torikumi ga jūbun'na no ka, kangaete iku koto ga taisetsudesu.

'Kalian tentunya sangat mengetahui kondisi saat ini tentang pemanasan global, apakah orang dewasa cukup bekerja? Merupakan hal yang semakin penting untuk dipikirkan.'

Dalam kalimat (14) terdapat kata kerja kangaete iku yang memiliki arti 'semakin memikirkan'. Makna -te iku dalam kata kerja kangaete iku adalah menyatakan aspek imperfektif, yaitu keadaan dari saat ini ke depan. Dalam hal ini posisi penutur tetap, sedangkan hal-hal penting tersebut jauh dari penutur. Kala dalam kalimat ini keyakinan kejadian masa depan karena diakhiri dengan kopula -desu. Dilihat dari konteks kalimat, masalah pemanasan global adalah hal penting yang harus semakin diperhatikan.

\section{KESIMPULAN}

Berdasarkan penelitian yang telah dilakukan, dapat ditarik simpulan sebagai berikut.

1. Jenis aspek yang terdapat pada kata kerja -te iku dan -te kuru adalah pada kata kerja -te kuru, terdapat aspek (1) imperfektif yang memiliki makna adanya perubahan keadaan yang awalnya tidak ada menjadi ada dan menyatakan keadaan yang akan berubah dari sekarang ke masa depan. (2) Aspek perfektif karena saat tuturan diucapkan, aktivitas tersebut mendekati waktu saat dituturkan. Pada kata kerja -te iku, terdapat aspek (1) imperfektif yang menunjukan fenomena yang saat ini terjadi dan belum berakhir dan keadaan yang akan terjadi dari saat ini ke masa depan.

2. Jenis kala yang terdapat pada kata kerja -te kuru dan -te iku adalah pada kata kerja -te kuru, terdapat (1) kala yang menyatakan kondisi saat ini dan keyakinan kejadian masa depan yang ditandai dengan akhiran bentuk -ru dan -masu yaitu -te kuru dan -te kimasu. (2) kala yang menyatakan kejadian masa lampau yang ditandai dengan bentuk - $t a$ yaitu -te kimashita. Pada kata kerja iku, terdapat (1) kala yang menunjukan kondisi saat ini dan keyakinan kejadian masa depan yang ditandai dengan bentuk -ru yaitu -te iku.

\section{DAFTAR PUSTAKA}

Alwi, H., dkk. (2005). Kamus Besar Bahasa Indonesia. Balai Pustaka.

Kridalaksana, H. (2009). Kamus Linguistik. Gramedia Pustaka Utama.

Chaer, A. (2012). Linguistik Umum. Rineka Cipta.

Teramura, H. (1998). Nihongo Kyooiku Handobukku.Oufu.

Iori, I., Takanashi, S., Nakanishi, K., \& Yamada, T. (2000). Shokyuu wo Oshieru Hito no Tameno Nihongo 
JLA (Jurnal Lingua Applicata), Vol. 3 No.2, 2020

Bunpou Handobukku. 3A Aryanto, B. (2008). Kala Dan Aspek Dalam Corporation.

Bahasa Jepang. Lite: Jurnal Bahasa,

Yasuhiko, K., \& Fukuchi, T. (1989). Tensu, Sastra, dan Budaya, 4 (2), 60-72.

Asupekuto, Muudo. Aratake

Shuppan.

Kajian Budaya Dan Ilmu Sosial

Humaniora Pada Umumnya.

Pustaka Pelajar. 